\title{
Dissolution kinetics and mechanisms of reaction of Udi clay in nitric acid solution
}

\author{
R. O. Ajemba and O. D. Onukwuli \\ Department of Chemical Engineering, Nnamdi Azikiwe University, P. M. B. 5025, \\ Awka, Anambra, Nigeria \\ ABSTRACT
}

\begin{abstract}
The dissolution kinetics and mechanisms of reaction of Udi clay in nitric acid have been studied. Leaching temperature, acid concentration, particle size, solid-to-liquid ratio, and stirring speed were selected as process parameters. It was observed that the dissolution rate increased with decreasing particle size and solid-to-liquid ratio and increased with stirring speed, acid concentration, and leaching temperature. The experimental results indicate that the dissolution rate is chemical reaction controlled via hydrogen ion $[\mathrm{H}+]$ action, with reaction order of 0.31 and the reaction kinetics can be expressed as: $1-(1-\mathrm{X}){ }^{1 / 3}=1.7275 \times 10^{4} \mathrm{C}_{[\mathrm{HNO}]}{ }^{0.3113}\left(\mathrm{~d}_{\mathrm{p}}\right)^{-0.4102}$ $(\mathrm{S} / \mathrm{L})^{-0.3104}(\mathrm{w})^{0.2709} \exp (-2621 / \mathrm{T}) \mathrm{t}$. The activation energy of the process was determined to be $21.791 \mathrm{~kJ} / \mathrm{mol}$. The experimental data were tested by graphical and statistical methods and it was found out that the above model best fitted the data.
\end{abstract}

Keywords: Dissolution, kinetics, shrinking core model, nitric acid, Udi clay.

\section{INTRODUCTION}

Leaching process is one of the most frequently employed techniques in extractive metallurgy for the recovery of value using aqueous solutions. Low energy consumption, reduced environmental pollution, and the ability to treat low grade ores are amongst attracting features which motivates its application in hydrometallurgical routes. Over the past few decades, numerous pieces of work were conducted on the dissolution of minerals aiming at understanding, controlling, and optimizing effects of process parameters on the extraction yield (Baba, et al, 2007 and 2010; Guillermo, et al, 2005; Girgin, et al, 2011; Ozmetin, et al, 1996; Martinez-Luevanos, et al, 2011; Abali, et al, 2007 and 2011; Demirkiran and Kunkul, 2008; Uzun and Gulfen, 2007; Ige et al, 2005; Numan and Weaver, 1969).

Brown et al, (1966), studied the production of alumina from clay mined at Delaware, USA, by dissolving the clay mineral in nitric acid solution of known concentration. They found out that the dissolution is dependent on the calcination temperature and time as well as the acid concentration. They recommended a calcination temperature and time of $700^{\circ} \mathrm{C}$ and one and half hours, respectively.

Hulbert, et al, (1970), studied the kinetics of alumina removal from calcined clay using sulphuric, hydrochloric, and nitric acids, they found out that the rate-controlling step for the leaching of aluminium ions from calcined clay when employing nitric acid was diffusion of reaction products from the phase boundary. They also reported that about $85 \%$ of alumina was removed using $160 \%$ concentration of the acid as other process parameters were kept at constant values.

Udi clay has not found any commercial application in the recent years, but, it is only used by local potters in their pottery work. The high content of alumina in the clay necessitated this research, as bauxite, which has remained the main raw source of alumina for aluminium industries in Nigeria, is depleting and the need for a substitute raw material.

In this work, the kinetics and mechanism of alumina removal from calcined Udi clay dissolved in nitric acid have been studied and the best dissolution conditions established.

Experimental Procedure: Clay sample was mined at Udi (N: $6^{\circ} 31^{\prime} 0.0^{\prime \prime}$; E: $7^{\circ} 43^{\prime} 0.0^{\prime \prime}$; A: $327 \mathrm{~m}$ ) in Enugu state southern part of Nigeria. The raw clay was sun-dried for three days and then crushed with pestle and mortar. The ground sample was sieved into different particle sizes ranging from 0.045 to $0.408 \mathrm{~mm}$. The sized samples were calcined at different temperatures in a muffle furnace and then dissolved in nitric acid solution. In the dissolution experiments, $100 \mathrm{ml}$ of the nitric acid of predetermined concentration was poured into a 250 $\mathrm{ml}$ spherical glass reactor equipped with a 
mechanical stirrer. The reactor and its content were placed inside a thermostatically controlled heating plate. Heat was applied and at the attainment of the desired temperature, $2 \mathrm{~g}$ of the sized clay sample was introduced into the reactor with constant stirring. At the completion of the period of reaction, the contents of the reactor were filtered using Whatman filter paper. The filtrate containing the aluminium nitrate was evaporated to dryness and the residue ignited at $1100^{\circ} \mathrm{C}$ to form oxide from the nitrate salt and was weighed. The fraction of the alumina removed $(x)$ was calculated by dividing the residue weight by the theoretical total alumina content of the calcined clay sample. The above experimental procedure was repeated to study the effect of the process parameters by varying their values as follows: acid concentration $(3-15 \mathrm{M})$; leaching temperature $(30-$ $\left.70^{\circ} \mathrm{C}\right)$; particle size $(0.045-0.408 \mathrm{~mm})$; solid-to-liquid ratio $(0.02-0.04 \mathrm{~g} / \mathrm{ml})$; and stirring speed $(90-720$ rpm).

\section{RESULTS AND DISCUSSION}

The chemical analysis of the raw and calcined (at $700^{\circ} \mathrm{C}$ for 80 minutes) Udi clay are given in Table 1. The calcined sample was used in the leaching experiments.

Table 1: Chemical analysis of the raw and calcined clay sample

\begin{tabular}{|l|l|l|l|l|l|l|l|l|l|}
\hline Composition (\%) & $\mathbf{S i O}_{2}$ & $\mathbf{A l}_{2} \mathbf{O}_{3}$ & $\mathbf{F e}_{2} \mathbf{O}_{3}$ & $\mathbf{C a O}$ & $\mathbf{M g O}$ & $\mathbf{S O}_{3}$ & $\mathbf{N a}_{2} \mathbf{O}$ & $\mathbf{K}_{\mathbf{2}} \mathbf{O}$ & $\mathbf{L O}$ \\
\hline Raw clay & 40.28 & 24.42 & 17.25 & 0.14 & 3.60 & 2.34 & 2.32 & 2.33 & 7.32 \\
\hline Calcined (at $700^{\circ} \mathrm{C}$ ) & 41.39 & 26.50 & 18.45 & 0.14 & 3.78 & 2.47 & 2.52 & 2.62 & 2.13 \\
\hline
\end{tabular}

When the clay is added to nitric acid solution, the reaction taking place in the medium could be represented as follows:

$\mathrm{Al}_{2} \mathrm{O}_{3(\mathrm{~s})}+6 \mathrm{HNO}_{3}(\mathrm{aq}) \longrightarrow 2 \mathrm{Al}\left[\mathrm{NO}_{3}\right]_{3(\mathrm{aq})}+3 \mathrm{H}_{2} \mathrm{O}_{(\mathrm{l})}$

(1)

\section{Dissolution of the clay sample}

Effect of calcination: To investigate the effect of calcination temperature and time on the dissolution reaction, the calcined samples were dissolved in nitric acid solution and the dissolution rate was measured by the fraction of alumina removed as a function of time as shown in Figure 1. The figure shows that the dissolution rate increased up to calcination temperature of $750^{\circ} \mathrm{C}$ above which there was a decrease in the fraction of alumina removed. As can be seen from the figure, the increase in the fraction removed in the range from $700^{\circ} \mathrm{C}$ to $750^{\circ} \mathrm{C}$ is not significant and so $700^{\circ} \mathrm{C}$ was chosen as the best temperature.

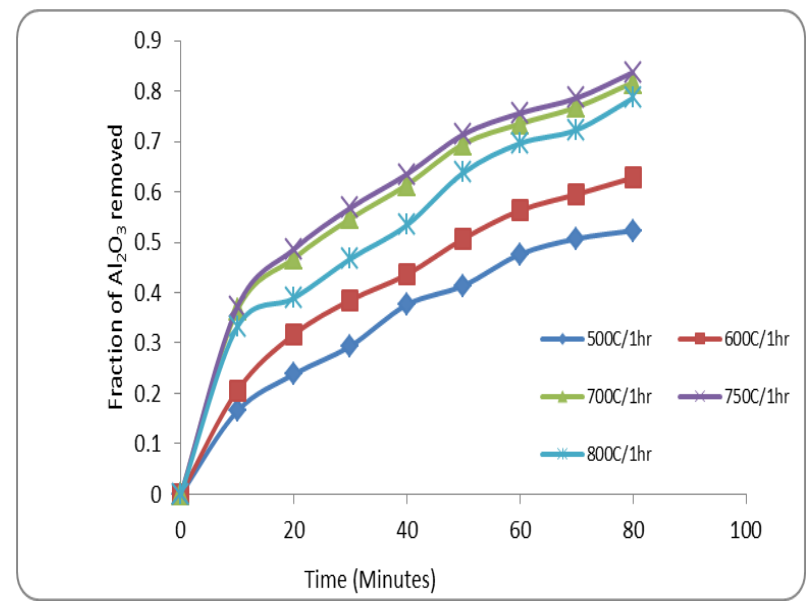

Fig 1: Effect of calcination temperature.

Effect of dissolution temperature: the temperature dependence of the dissolution of clay mineral on temperature was determined by dissolving the clay sample in $12 \mathrm{M}$ nitric acid solution at different temperatures of $30,40,50,60$, and $70^{\circ} \mathrm{C}$. The obtained results are presented in Figure 2 and the figure shows that the dissolution rate of alumina are extremely increased by temperature and the best result was recorded at $70^{\circ} \mathrm{C}$. 
Am. J. Sci. Ind. Res., 2012, 3(3): 115-121

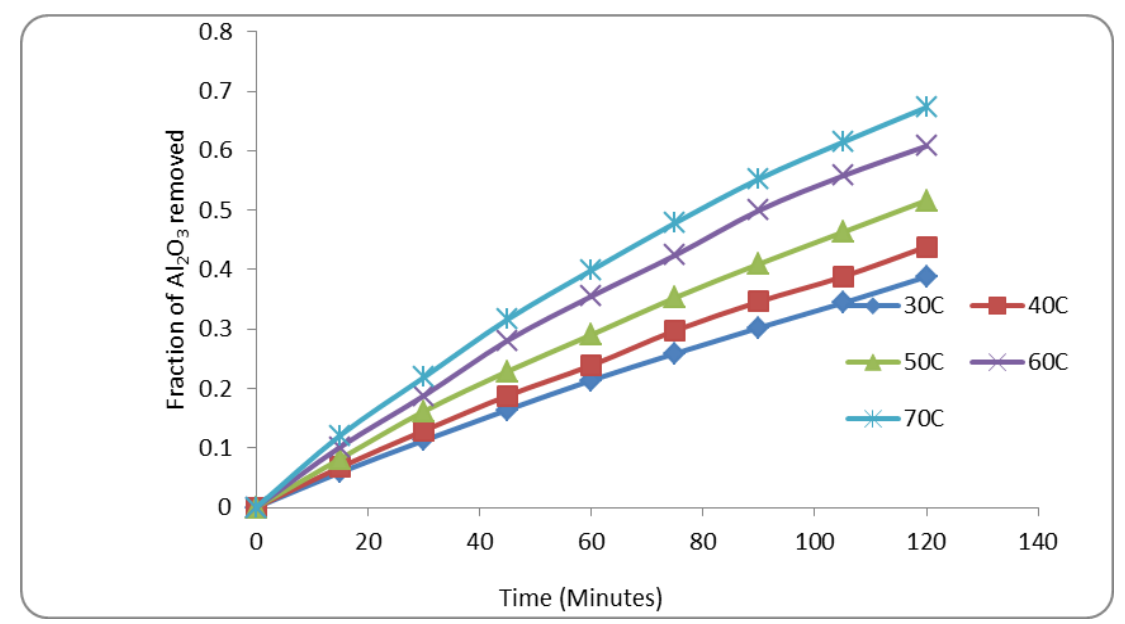

Fig 2: Effect of leaching temperature (calcined at $700^{\circ} \mathrm{C}$ for $1 \mathrm{hr}$; concentration, $12 \mathrm{M}$; stirring, $540 \mathrm{rpm}$; leaching time, $60 \mathrm{mins}$; solid/liquid ratio, $0.02 \mathrm{~g} / \mathrm{ml}$ ).

Effect of nitric acid concentration: Effect of nitric acid concentration was examined by varying the concentrations of the acid solution from $3,6,9,12$, to $15 \mathrm{M}$. The experimental data are presented in Figure 3. The figure shows that as the concentration increases, the fraction removed increases and the optimum nitric acid concentration within the experimental conditions was determined to be $15 \mathrm{M}$.

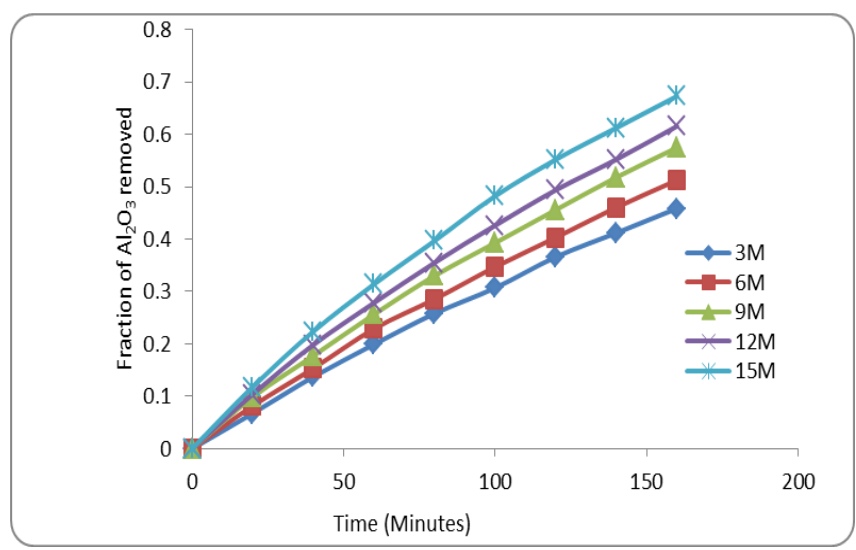

Fig 3: Effect of acid concentration ( $2 \mathrm{~g}$ clay calcined at $700^{\circ} \mathrm{C}$ for $1 \mathrm{hr} ; 0.02 \mathrm{~g} / \mathrm{ml} ; 12 \mathrm{M} \mathrm{HNO}_{3} ; 540 \mathrm{rpm} ; 0.045 \mathrm{~mm}$ particle size)
Effect of particle size: The clay samples of different particle sizes ranging from 0.045 to $0.408 \mathrm{~mm}$ were dissolved in the solution of nitric acid. It was observed that the dissolution rate increased with decreasing particle size and experimental data is shown in Figure 4.

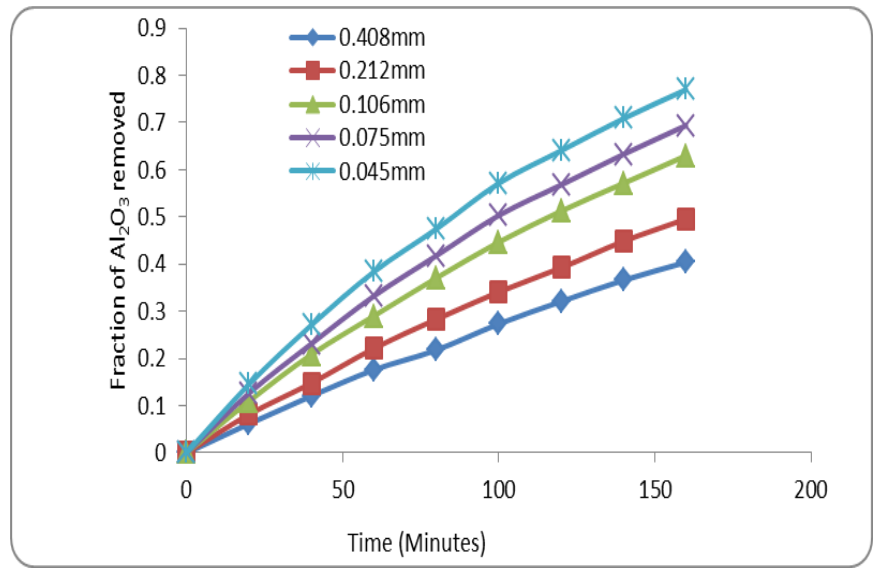

Fig 4: Effect of particle size $\left(2 \mathrm{~g}\right.$ clay calcined at $700^{\circ} \mathrm{C}$ for $1 \mathrm{hr} ; 0.02 \mathrm{~g} / \mathrm{ml}$ solid/liquid ratio; $12 \mathrm{M} \mathrm{HNO}_{3} ; 540 \mathrm{rpm}$; $70^{\circ} \mathrm{C}$ leaching temp.).

Effect of solid-to-liquid ratio: The effect solid-toliquid ratio on the dissolution rate of the clay sample was investigated using different ratios ranging from $0.02,0.04,0.06,0.08$, to $0.10 \mathrm{~g} / \mathrm{ml}$. The experimental 
data show that dissolution rate increases with decreasing solid-to-liquid ratio as shown in Figure 5. The best ratio was chosen as $0.02 \mathrm{~g} / \mathrm{ml}$.

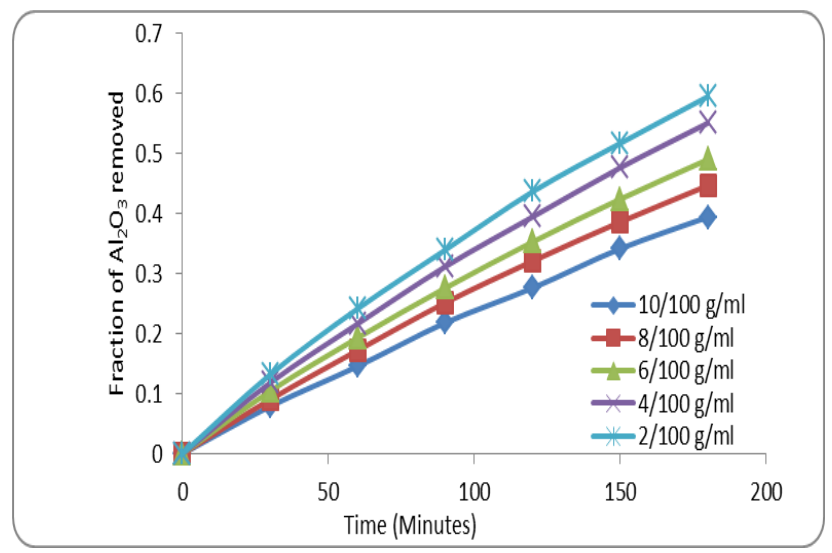

Fig 5: Effect of solid-to-liquid ratio (calcined at $700^{\circ} \mathrm{C}$ for $1 \mathrm{hr} ; 12 \mathrm{M} \mathrm{HNO}{ }_{3} ; 540 \mathrm{rpm} ; 0.045 \mathrm{~mm}$ particle size; $70^{\circ} \mathrm{C}$ leaching temp).

Effect of stirring speed: The experimental results are shown in Figure 6. It was observed that the dissolution rate increased as the stirring speed increased, but the increase was less at speed above $540 \mathrm{rpm}$ which was chosen as the best speed.

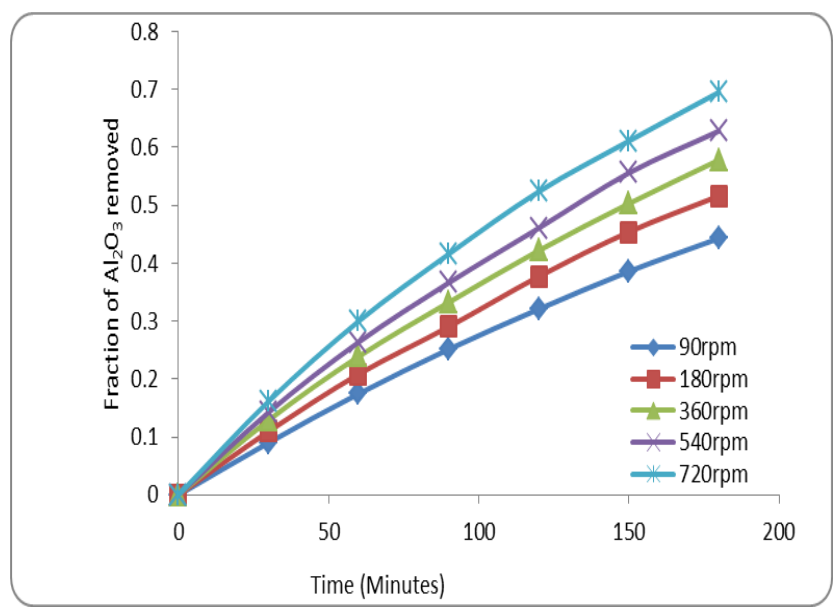

Fig 6: Effect of stirring speed $\left(2 \mathrm{~g}\right.$ calcined at $700^{\circ} \mathrm{C}$ for $1 \mathrm{hr} ; 12 \mathrm{M} \mathrm{HNO}_{3} ; 70^{\circ} \mathrm{C}$ leaching temp.; $0.045 \mathrm{~mm}$ particle size; $0.02 \mathrm{~g} / \mathrm{ml}$ solid/liquid ratio).

Dissolution kinetics: In order to establish the kinetic parameters and rate-controlling step for the dissolution of alumina in nitric acid solution, the experimental data plotted in Figures 2, 3, 4, 5, and 6, that represent the dissolution of Udi clay using nitric acid, were fitted to the shrinking core kinetic. According to the shrinking core model, reaction rate of a heterogeneous process may be controlled by one of the following steps:

Film diffusion control:

$\mathrm{X}=6 \mathrm{~b} D \mathrm{C}_{\mathrm{A}} / \mathrm{\rho}_{\mathrm{B}} \mathrm{R}_{0}^{2} \mathrm{t}=\mathrm{k}_{1} \mathrm{t}$

Surface chemical reactions control:

$1-(1-\mathrm{X})^{1 / 3}=6 \mathrm{~b} D \mathrm{C}_{\mathrm{A}} / \rho_{\mathrm{B}} \mathrm{R}_{\mathrm{o}}{ }^{2} \mathrm{t}=\mathrm{k}_{2} \mathrm{t}$

Product layer diffusion control:

$1+2(1-X)-3(1-X)^{2 / 3}=6 b D C_{A} / \rho_{B} R_{0}^{2} t=k_{3} t$

Where $\rho_{B}$ is the molar density of solid reactant $\left(\mathrm{mol} / \mathrm{m}^{3}\right), R_{0}$ is the radius of a sphere $(\mathrm{m}), b$ is the stoichiometric coefficient of the solid, $D$ is the effective diffusion coefficient $\left(\mathrm{m}^{2} / \mathrm{s}\right)$ and $\mathrm{C}_{\mathrm{A}}$ is the concentration of $A$ in the bulk solution $\left(\mathrm{mol} / \mathrm{m}^{3}\right)$.

It was found out that the experimental data fitted very well to the chemical reaction control of a spherical particle of the shrinking core model. The plots of the fitted equations for the process parameters are shown in Figures 7, 8, 9, 10, and 11, for temperature, acid concentration, particle size, solid/liquid ratio, and stirring rate, respectively.

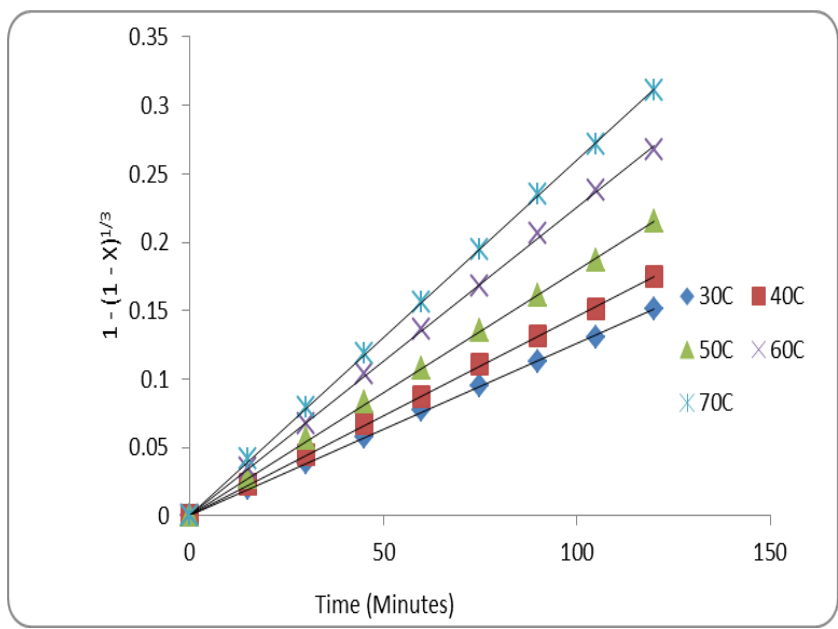

Fig 7: Plot of $1-(1-X)^{1 / 3}$ versus time at different temperature. 
Am. J. Sci. Ind. Res., 2012, 3(3): 115-121
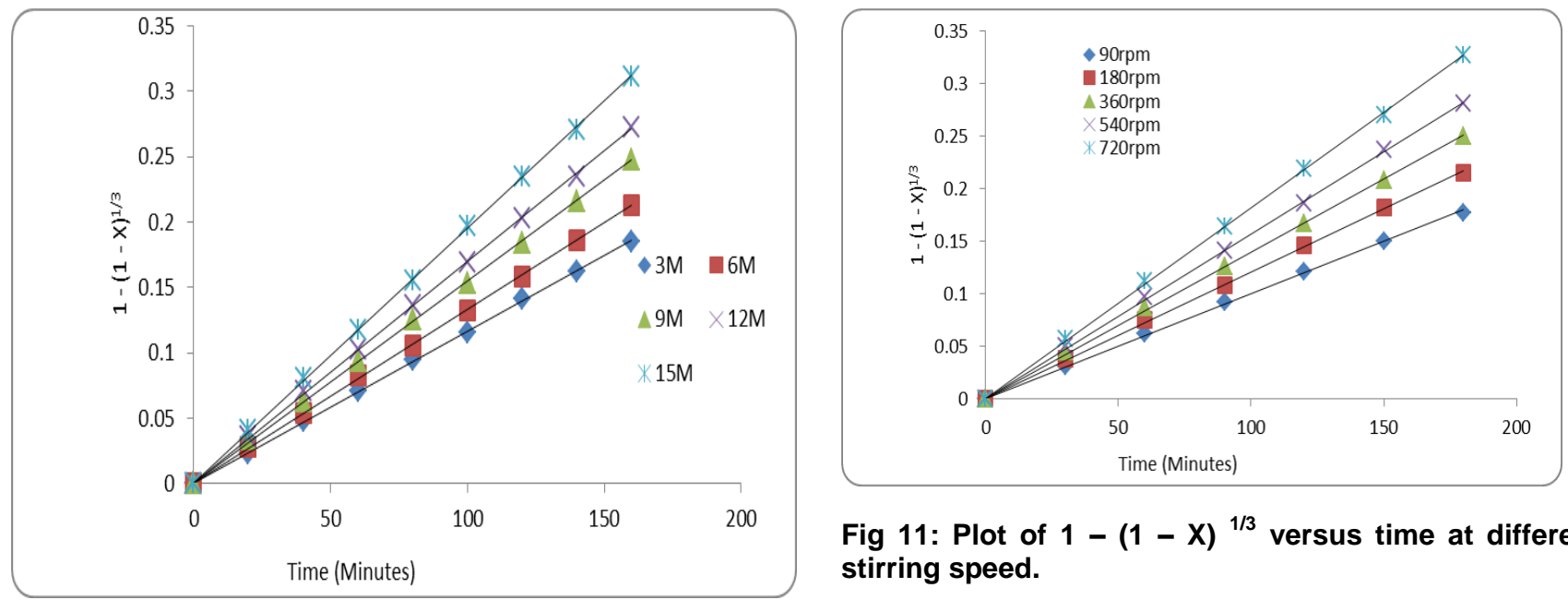

Fig 11: Plot of $1-(1-X){ }^{1 / 3}$ versus time at different stirring speed.

Fig 8: Plot of $1-(1-X){ }^{1 / 3}$ versus time at different acid concentrations.
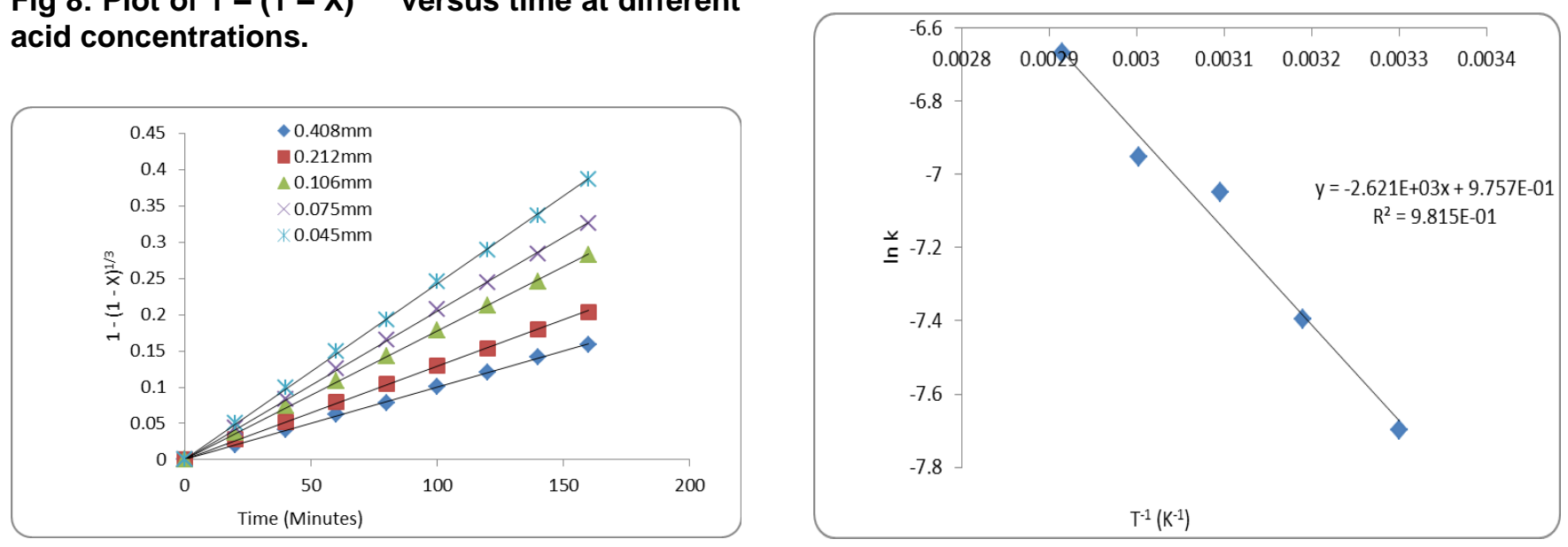

Fig 9: Plot of $1-(1-X)^{1 / 3}$ versus time at different particle sizes.

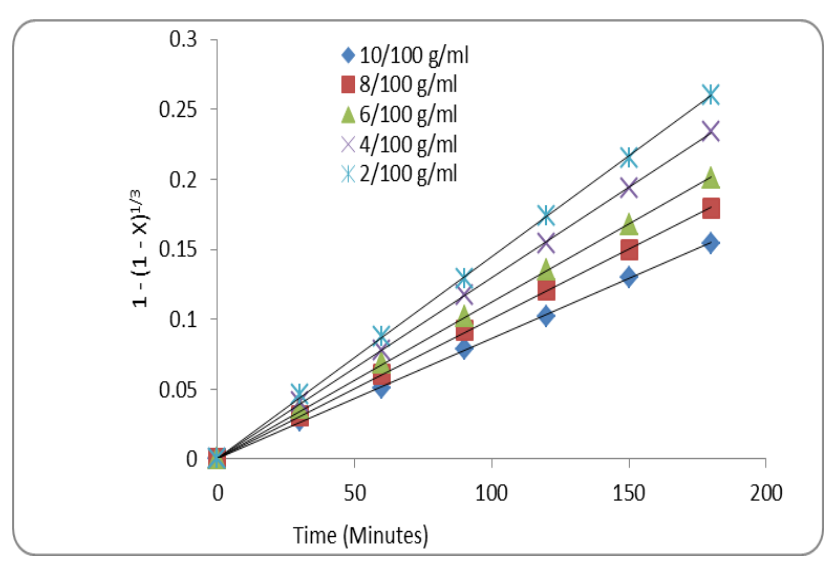

Fig 10: Plot of $1-(1-X){ }^{1 / 3}$ versus time at different solid-to-liquid ratios.

Fig 12: Plot of In $k_{\text {versus }} \mathrm{T}^{-1}$.

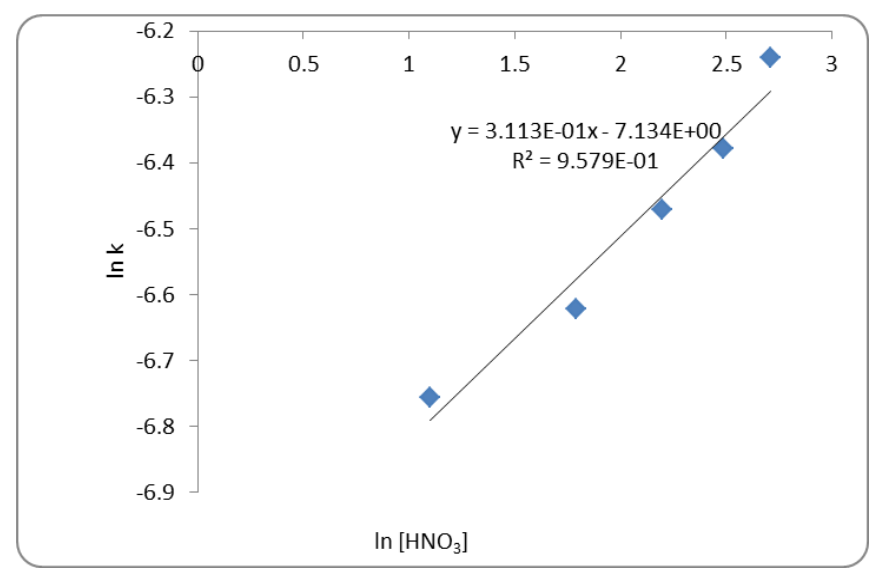

Fig 13: Plot of In $\mathrm{k}$ versus $\ln \left[\mathrm{HNO}_{3}\right]$. 
Am. J. Sci. Ind. Res., 2012, 3(3): 115-121

The apparent reaction rate constants calculated from the slopes of Figure 7, were plotted against the reciprocal of the temperature according to the Arrhenius equation to determine the activation energy of the process. The plot of the data is shown in Figure 12; the activation energy was determined to be $21.791 \mathrm{~kJ} / \mathrm{mol}$ with a correlation coefficient of 0.9815 , which is in close agreement with the value calculated by Gahrke et al (2005) of $18.642 \mathrm{~kJ} / \mathrm{mol}$ for Serbian montmorillonite using oxalic acid.

The apparent reaction rate constants calculated from the slopes of Figures 8, 9, 10, and 11, for acid concentration, particle size, solid-to-liquid ratio, and stirring speed, respectively, were plotted against the natural logarithm of the respective parameter values to determine their effect on the kinetics of the dissolution of Udi clay in nitric acid. The plots are shown in Figures 13, 14, 15, and 16, for acid concentration, particle size, solid/liquid ratio, and stirring speed, respectively.

A semi-empirical model is also developed for the process as follows;

$1-(1-X)^{1 / 3}=k_{0} C_{[H N O 3]}{ }^{a}\left(d_{p}\right)^{b}(S / L)^{c}(w)^{d} \exp \left(-E_{a} / R T\right) t$

The variables $a, b, c$, and $d$, are determined from the slopes of Figures 13, 14, 15, and 16, respectively; they are calculated to be $0.3113,-0.4102,-0.3104$, and 0.2709. Substituting these values in Equation (5), the dissolution of Udi clay in nitric acid could be described by the following equation:

$1-(1-\mathrm{X})^{1 / 3}=1.7275 \times 10^{4} \mathrm{C}_{[\mathrm{HNO}]}{ }^{0.3113}\left(\mathrm{~d}_{\mathrm{p}}\right)^{-0.4102}(\mathrm{~S} / \mathrm{L})$

The apparent reaction rate constants of the tested models are presented in Table 2. The comparison of analyzed data based on the linear regression coefficient $\left(R^{2}\right)$ values (Table 2 ) for different kinetic model equations showed the orders followed are surface chemical reaction of a spherical particle > film diffusion controls $>$ ash product layer diffusion of a spherical particle. Hence, the surface chemical reaction of a spherical particle kinetic equation (Eq. (2)), in general, has best agreed to the present kinetic reactions.
Table 2: Values of apparent rate constants and the correlation coefficients

\begin{tabular}{|c|c|c|c|c|c|c|}
\hline \multirow{3}{*}{$\begin{array}{l}\text { Process } \\
\text { parameter }\end{array}$} & \multicolumn{6}{|c|}{ Kinetic equation } \\
\hline & \multicolumn{2}{|c|}{$\begin{array}{l}X=k_{1} t \text { (film } \\
\text { diffusion } \\
\text { control) }\end{array}$} & \multicolumn{2}{|c|}{$\begin{array}{l}1-(1-X)^{1 / 3}= \\
k_{2} t \quad(\text { chemical } \\
\text { reaction } \\
\text { control) }\end{array}$} & \multicolumn{2}{|c|}{$\begin{array}{l}1+2(1-X)- \\
3(1-X)= \\
k_{3} t \text { (ash layer } \\
\text { diffusion } \\
\text { control) }\end{array}$} \\
\hline & $\begin{array}{l}K_{1} \mathrm{X} \\
10^{-3}\end{array}$ & $\mathrm{R}^{2}$ & $\begin{array}{l}\mathrm{k}_{2} \mathrm{x} \\
10^{-3}\end{array}$ & $\mathrm{R}^{2}$ & $\begin{array}{l}K_{3} \times \\
10^{-3}\end{array}$ & $\mathrm{R}^{2}$ \\
\hline \multicolumn{7}{|l|}{$\operatorname{Temp}\left({ }^{\circ} \mathrm{C}\right)$} \\
\hline 30 & 3.349 & 0.9937 & 1.261 & 0.9992 & 0.414 & 0.8894 \\
\hline 40 & 3.801 & 0.9925 & 1.459 & 0.9991 & 0.547 & 0.8893 \\
\hline 50 & 4.523 & 0.9882 & 1.795 & 0.9990 & 0.807 & 0.8891 \\
\hline 60 & 5.432 & 0.9838 & 2.258 & 0.9988 & 1.233 & 0.8890 \\
\hline 70 & 6.043 & 0.9776 & 2.601 & 0.9989 & 1.590 & 0.8768 \\
\hline \multicolumn{7}{|l|}{ Con. (M) } \\
\hline 3 & 3.004 & 0.9917 & 1.164 & 0.9991 & 0.461 & 0.8918 \\
\hline 6 & 3.357 & 0.9899 & 1.330 & 0.9989 & 0.592 & 0.8885 \\
\hline 9 & 3.791 & 0.9865 & 1.546 & 0.9989 & 0.783 & 0.8907 \\
\hline 12 & 4.079 & 0.9834 & 1.697 & 0.9990 & 0.928 & 0.8932 \\
\hline 15 & 4.531 & 0.9772 & 1.950 & 0.9992 & 1.192 & 0.9017 \\
\hline \multicolumn{7}{|l|}{$\begin{array}{l}\text { Part. size } \\
(\mathrm{mm})\end{array}$} \\
\hline 0.045 & 5.283 & 0.9622 & 1.003 & 0.9989 & 0.347 & 0.9005 \\
\hline 0.075 & 4.697 & 0.9724 & 1.287 & 0.9990 & 0.556 & 0.8999 \\
\hline 0.106 & 4.222 & 0.9789 & 1.773 & 0.9989 & 1.003 & 0.8997 \\
\hline 0.212 & 3.269 & 0.9882 & 2.047 & 0.9991 & 1.297 & 0.8998 \\
\hline 0.408 & 2.644 & 0.9927 & 2.424 & 0.9990 & 1.746 & 0.8989 \\
\hline \multicolumn{7}{|l|}{$\begin{array}{l}\mathrm{S} / \mathrm{L} \text { ratio } \\
(\mathrm{g} / \mathrm{ml})\end{array}$} \\
\hline 0.02 & 3.491 & 0.9858 & 0.859 & 0.9997 & 0.293 & 0.8895 \\
\hline 0.04 & 3.205 & 0.9897 & 1.003 & 0.9996 & 0.392 & 0.8975 \\
\hline 0.06 & 2.853 & 0.9899 & 1.123 & 0.9995 & 0.485 & 0.8969 \\
\hline 0.08 & 2.594 & 0.9919 & 1.296 & 0.9993 & 0.634 & 0.8908 \\
\hline 0.10 & 2.271 & 0.9949 & 1.444 & 0.9994 & 0.773 & 0.8965 \\
\hline \multicolumn{7}{|l|}{$\begin{array}{l}\begin{array}{l}\text { Stir. } \\
\text { Speed } \\
(\mathrm{rpm})\end{array} \\
\end{array}$} \\
\hline 90 & 2.588 & 0.9902 & 0.999 & 0.9992 & 0.388 & 0.9031 \\
\hline 180 & 3.031 & 0.9884 & 1.209 & 0.9991 & 0.556 & 0.8998 \\
\hline 360 & 3.398 & 0.9842 & 1.394 & 0.9991 & 0.723 & 0.9002 \\
\hline 540 & 3.722 & 0.9820 & 1.568 & 0.9990 & 0.898 & 0.9002 \\
\hline 720 & 4.150 & 0.9753 & 1.817 & 0.9992 & 1.168 & 0.9056 \\
\hline
\end{tabular}


Conclusion: The conclusions that can be drawn from the dissolution of alumina in nitric acid solution are:

(iii) The rate of alumina dissolution followed the chemical reaction controlled mechanism, $1-(1-X)^{1 / 3}$ $=1.7275 \times 10^{4} C_{[H N O 3]} 0.3113\left(d_{p}\right)^{-0.4102}$ $(S / L)^{-0.3104}(w)$ l. $^{0.2109} \exp (-2621 / T)$, with an apparent activation energy of $21.791 \mathrm{~kJ} / \mathrm{mol}$.

\section{REFERENCES}

Alafara A. B., Adekola F. A., (2010). Hydrometallurgical processing of a Nigerian sphalerite in hydrochloric acid: characterization and dissolution kinetics. Hydrometallurgy, 101, $69-75$.

Baba A. A, F. A. Adekola, O. I. Dele-lge, R. B. Bale, (2007). Investigation of dissolution kinetics of a Nigerian tantalite ore in nitric acid. Journal of Minerals \& Materials Characterization \& Engineering, 7 (1), 83 95.

Deger Uzun, Mustafa Gulfen, (2007). Dissolution kinetics of iron and aluminium from red mud in sulphuric acid solution. Indian Journal of Chemical Technology, 14, $263-268$.

Gahrke T., Pina P. S., Cornell R. M., (2005). Dissolution kinetics of montmorillonite in hydrochloric and oxalic acid. Journal of American Society, 114, 102 - 112.
Guillermo D. T. Calderon, Jorge I. Rodriguez, U. OrtizMendez, Leticia M. Torres-Martinez, (2005). Iron leaching of a Mexican clay of industrial interest by oxalic acid, Journal of Materials Online Azojomo. http://www.azom.com/oars.asp.

Ismail Girgin, Abdullah Obut, Ayse Ucyildiz, (2011). Dissolution behaviour of a Turkish laterite nickel ore, Minerals Engineering, 24, 603 - 609.

Jide Ige, M. S. Akanni, M. K. Morakinyo, O. Owoyomi, (2005). A kinetic study of the leaching of iron and manganese from a Nigerian tantalite-columbite ore. Journal of Applied Sciences, 5 (3), 496 - 502.

Martinez-Luevanos A., M. G. Rodriguez-Delgado, A. UribeSalas, F. R. Carrillo-Pedroza, J. G. Osuna-Alarcon, (2011). Leaching kinetics of iron from low grade kaolin by oxalic acid solutions. Applied Clay Science, 51, 473 -477 .

N. Demirkiran, A. Kunkul, (2008). Dissolution kinetics of ulexite prepared under different calcination temperatures. Brazilian Journal of Chemical Engineering, 25 (4), 751 - 758. Numan Abdul-Latif, Charles E. Weaver, (1969). Kinetics of acid-dissolution of palygorskite (attapulgite) and sepiolite. Clays and Clay Minerals, 17, 169 - 178. S. F. Hulbert, D. E. Huff, (1970). Kinetics of alumina removal from a calcined kaolin with nitric, sulphuric, and hydrochloric acids. Clay Minerals, 8, 337 - 345. William H. Brown, Kizhakke G. Hrishikesan, (1966). Process for the production of alumina from clay, U. S. Patents online.

Yuksel Abali, Salih U. Bayca, Elvan Mistincik, (2011). Leaching kinetics of ulexite in oxalic acid, Physicochem. Probl. Miner. Process., 47, 139 - 148.

Yuksel Abali, Seda Kelesoglu, Julide Kaymak, (2007). Dissolution kinetics of calcinated manganese ore in acetic acid solutions. C. B. U. Journal of Science, 3.1, $81-88$. 